Volume 2, No 2, Agustus 2021

\title{
PENGARUH KUALITAS PELAYANAN TELLER TERHADAP KEPUASAN NASABAH DI BMT UGT CAPEM KETOMPEN PAJARAKAN
}

\author{
Hayatul Millah ${ }^{1}$ Rohmawati $^{2}$ \\ ${ }^{1}$ Fakultas Ekonomi dan Bisnis Islam, Universitas Islam Zainul Hasan Genggong \\ Probolinggo \\ ${ }^{2}$ Fakultas Ekonomi dan Bisnis Islam, Universitas Islam Zainul Hasan Genggong \\ Probolinggo
}

\begin{abstract}
ABSTRAK
This study aims to determine the effect of teller service quality on customer satisfaction. This research is a quantitative descriptive research, which is a method that explains or analyzes a problem from a data based on the calculation of numbers with statistical analysis of the research results. The results showed that the quality of teller service $(X)$ had a positive and significant effect on customer satisfaction (Y). That is, if the quality of teller service increases, then customer satisfaction will also increase. On the other hand, if the quality of teller service decreases, customer satisfaction will also decrease.
\end{abstract}

Keyword: Kualitas Pelayanan ; Kepuasan Nasabah

\section{PENDAHULUAN}

Perkembangan ekonomi sangat pesat pada saat ini, terutama dalam lembaga keuangan. Saat ini banyak bermunculan lembaga-lembaga keuangan baik lembaga keuangan di sektor perbankan maupun nonperbankan, sehingga dapat menjadikan lembaga keuangan merupakan salah satu instrumen keuangan modern yang mempunyai nilai strategis dalam kehidupan perekonomian disuatu negara. Saat ini mulai banyak berdiri perusahaan yang bergerak dibidang jasa keuangan micro menengah seperti Baitul Mal wa Tamwil atau lebih dikenal dengan sebutan BMT. Masyarakat mulai menyadari bahwa 
lembaga keuangan syari'ah juga merupakan kebutuhan untuk bermuamalah secara islami agar terhindar dari praktek-praktek riba atau yang mengandung unsur gharar, karena merupakan hal yang dilarang oleh islam dan juga telah memberikan dampak negatif terhadap ekonomi Islam.

Kepuasan nasabah adalah tolak ukur dalam mengetahui tingkat suatu kebutuhan, keinginan dan harapan supaya dapat mengakibatkan terjadinya suatu keinginan untuk selalu bertransaksi di perusahaan tersebut. Perusahaan juga melakukan beberapa cara agar membentuk kepuasan nasabah dengan cara memberikan pelayanan yang baik. Setiap bank memiliki standar operasional pelayanan yang telah ditentukan, hal ini dilakukan untuk memberikan pelayanan yang terbaik kepada nasabah. Salah satu ujung tombak pelayanan dalam sebuah bank adalah Frontliner. Frontliner merupakan bagian paling penting bagi bank, karena dapat menggambarkan baik tidaknya perusahaan dalam memberikan kepuasan kepada nasabah. Teller merupakan seorang petugas bank yang bertugas melayani nasabahnya dalam transaksi keuangan tunai atau non tunai kepada nasabah. Teller juga merupakan garis terdepan atau Frontliner bank yang sering di nilai sebagai standar profesional sebuah bank karena sikap teller merupakan cerminan bank tersebut. oleh sebab itu teller sangatlah berperan penting terhadap kredibilitas suatu bank. Selain memberikan pelayanan kegiatan transaksi-transaksi nasabah, teller juga harus dapat memberikan pelayanan yang terbaik kepada nasabahnya seperti mendengarkan keluhan-keluhan atau hal-hal yang tidak dimengerti oleh nasabahnya tersebut (Yashinta Mayangsari, 2020).

Kepuasan nasabah atas pelayanan teller akan memberikan dampak yang positif bagi bank, karena pelayanan yang baik maka akan dapat mendorong nasabahnya dalam menjalin hubungan yang baik dengan bank dan dapat memberikan kontribusi kepada perusahaan untuk meningkatkan pendapatan dalam jangka panjang.

Salah satu BMT terbesar di Indonesia saat ini adalah Koperasi BMT Usaha Gabungan Terpadu Sidogiri atau disingkat "BMT UGT Sidogiri”, BMT ini telah berusia 14 tahun dan sudah memiliki 440 unit layanan per cabang. Salah satu Cabangnya adalah BMT UGT Capem Ketompen Pajarakan yang sekarang sudah mempunyai nasabah sebanyak 2.978 orang. Perkembangan Nasabah BMT UGT Capem Ketompen Pajarakan dari tahun ke tahun selalu meningkat. jumlah nasabah BMT UGT Ketompen Padjarakan selalu 
meningkat setiap tahunnya.Peningkatan setiap tahunnya 13\% - 29\%. Seperti dari tahun 2015 terdapat 1.100 nasabah pada tahun 2016 meningkat menjadi 1.553 Nasabah atau terjadi kenaikan sebesar 29\% dari tahun sebelumnya, pada tahun 2017 sampai dengan tahun juli/2020 terjadi kenaikan jumlah nasabah sebesar 1.877, 2.225, 2.600,2.978 nasabah meningkat berturut turut dari tahun ke tahun atau dalam presentase meningkat sebesar $17 \%$ $, 16 \%, 14 \%, 13 \%$.

Kenaikan jumlah nasabah diatas tidak terlepas dari tingkat pelayanan yang maksimal yang telah diberikan oleh pihak BMT UGT Sidogiri Capem Pajarakan, termasuk didalamnya adalah pelayanan frontliner yang baik seperti, ramah, senyum dan proses transaksi yang cepat dan akurat.

\section{KAJIAN TEORI}

\section{Kualitas Pelayanan}

Kualitas pelayanan adalah suatu aktifitas atau serangkaian aktifitas yang bersifat tidak kasat mata yang terjadi akibat adanya interaksi antara konsumen dengan karyawan atau hal-hal lain yang disediakan oleh perusahaan. Pemberian pealayanan yang di maksud untuk memecahkan permasalahan konsumen atau pelanggan.kualitas pelayanantingkat keunggulan suatu perusahaan untuk memenuhi keinginan atau harapan konsumen (Lie Darwin, Efendi, Dan Andy Wijaya. 2017).

Parasuraman et al. dalam Lupiyoadi mengidentifikasi lima dimensi pelayanan yang berkualitas (Aida W. et al . 2014), yaitu:

a. Bentuk Fisik (tangibles)

Merupakan kemampuan suatu perusahaan dalam menunjukkan eksistensi kepada pihak eksternal. Penampilan dan kemampuan sarana dan prasarana fisik perubahan serta keadaan lingkungan sekitarnya merupakan bukti nyata dari pelayanan yang diberikan oleh pemberi jasa.

b. Kehandalan (reliability)

Merupakan kemampuan perusahaan untuk memberikan pelayanan sesuai yang dijanjikan secara akurat dan terpercaya. Atribut yang ada dalam dimensi kehandalan ini 
seperti memberikan pelayanan sesuai janji, pertanggung jawaban tentang penanganan pelanggan akan masalah pelayanan dan memberikan layanan tepat waktu.

c. Ketanggapan (responsiveness)

Merupakan kemauan untuk membantu dan memberikan pelayanan yang cepat (responsif) dan tepat kepada nasabah dengan penyampaian informasi yang jelas.

d. Jaminan (assurance)

Merupakan pengetahuan, kesopansantunan dan kemampuan para pegawai perusahaan untuk menumbuhkan rasa percaya para pelanggan kepada perusahaan. Terdiri dari beberapa komponen antara lain komunikasi (communication), kredibilitas (credibility), keamanan (security), kompetensi (competence) dan sopan santun (courtesy).

e. Empati (empathy)

Merupakan memberikan perhatian yang tulus dan bersifat individual atau pribadi yang diberikan kepada para nasabah dengan berupaya memahami keinginan nasabah. Kualitas pelayanan mempunyai hubungan erat terhadap kepuasan pelanggan, kualitas pelayanan peusahaan yang ditunjukkan kepada pelanggan merupakan elemen yang sangat penting agar dapat menjamin kelangsungan hidup atau menjaga kestabilan usaha perusahaan, karena perusahaan sangat mengharapkan rasa puas dalam diri nasabah.

\section{Kepuasan Nasabah}

Kepuasan nasabah adalah tingkat perasaan seseorang setelah membandingkan kinerja (atau hasil) yang dirasakan dibandingkan dengan harapannya nasabah. Menurut Philip Kotler mendefinisikan kepuasaan adalah perasaan senang seseorang yang muncul setelah membandingkan antara persepsi atau kesannya terhadap kinerja atau hasil suatu produk dan harapan-harapannya (Purwaningsih, Endang dan Nurul Huda, dkk, 2018).

Sedangkan definisi kepuasan pelanggan yang dirumuskan Richard Oliver kepuasan adalah tanggapan pelanggan atas terpenuhinya kebutuhannya. Hal itu berarti penilaian bahwa suatu bentuk keistimewaan dari suatu barang atau jasa itu sendiri, memberikan tingkatkenyamanan yang terkait dengan pemenuhan suatu kebutuhan, termasuk pemenuhan kebutuhan di bawah harapan atau pemenuhan kebutuhan melebihi harapan pelanggan.

Nasabah dapat mengalami salah satu dari tingkat kepuasan diantaranya: 
a. Apabila kinerja lebih rendah dari apa yang diharapkan oleh nasabah, maka nasabah akan tidak merasa puas, karena harapannya lebih tinggi dari pada yang diterima nasabah.

b. Bila kinerja sesuai apa yang di harapkan nasabah, maka nasabah akan merasa puas karena nasabah puas karena harapannya sesuai dengan apa yang diinginkan nasabah.

c. Bila kinerja melebihi dari harapan nasabah, maka nasabah akan merasa sangat puas, karena melebihi apa yang di harapkan (Agus, 2018).

\section{METODOLOGI PENELITIAN}

Jenis penelitian ini adalah penelitian deskriptif kuantitatif, penelitian deskriptif kuantitatif adalah metode yang menjelaskan atau menganalisis suatu permasalahan dari suatu data berdasarkan perhitungan angka-angka dengan analisis statistik dari hasil penelitian (Sugiyono, 2016). Dimana dalam penelitian ini menjelaskan dan menggambarkan kinerja teller BMT UGT dalam pelayanan yang diberikan kepada nasabah, yang bertujuan untuk mengetahui kepuasan nasabah dalam pelayanan kinerja dari karyawan perusahaan atau organisasi yang bersangkutan.

\section{HASIL DAN PEMBAHASAN}

\section{Hasil Penelitian}

Pengujian pengaruh kualitas pelayanan (X) terhadap kepuasan nasabah (Y), maka digunakan uji regresi linier sederhana. Hasil dari pengujian regresi linier sederhana pada masing-masing variabel sebagai berikut:

Tabel 1

\begin{tabular}{|c|c|c|c|c|}
\hline \multirow[b]{2}{*}{ Model } & \multicolumn{2}{|c|}{$\begin{array}{l}\text { Unstandardized } \\
\text { Coefficients }\end{array}$} & $\begin{array}{c}\text { Standardi } \\
\text { zed } \\
\text { Coefficie } \\
\text { nts }\end{array}$ & \\
\hline & B & Error & Beta & $\mathrm{T}$ \\
\hline $1 \quad$ (Constant) & 7.803 & 3.221 & & 2.423 \\
\hline
\end{tabular}




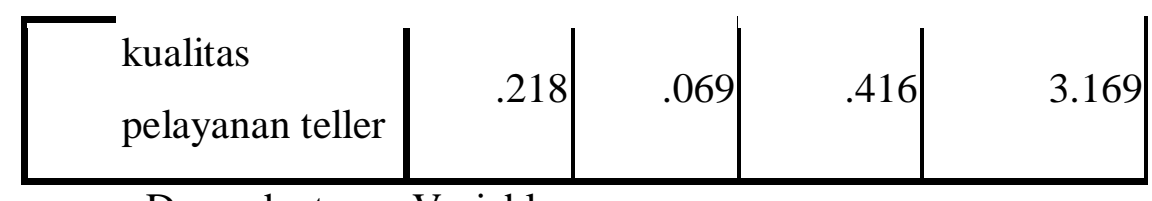

a. Dependent Variable:

kepuasan nasabah

Berdasarkan tabel 1 di atas, maka hasil yang diperoleh dimasukkan dalam persamaan sebagai berikut:

$\mathrm{Y}=\mathrm{a}+\mathrm{bX}$

$\mathrm{Y}=7.803+0,416 \mathrm{X}$

a. Konstanta sebesar 7.803.

b. Koefisien regresi X sebesar 0.416 menyatakan bahwa setiap penambahan $1 \%$ nilai kualitas pelayanan maka nilai kepuasan nasabah bertambah sebesar 0.416. Nilai T hitung 3.169 sudah lebih besar dari T tabel ( 2.021, df $=40$ ) artinya disini Ho ditolak dan Ha diterima, sehingga dapat ditarik kesimpulan bahwa kualitas pelayanan teller berpengaruh positif dan signifikan terhadap kepuasan nasabah.

\section{Koefisien Determinasi (R2)}

Koefisien determinasi adalah mengukur seberapa jauh kemampuan model dalam menerangkan variasi dependen. Nilai koefisien determinasi adalah antara nol dan satu. Nilai koefisien determinasi (R2) yang di uji dengan menggunakan SPSS 16 dapat dilihat pada tabel dibawah ini:

Tabel 2

Uji Determinasi

\begin{tabular}{|l|r|r|r|r|}
\hline Model & \multicolumn{1}{|c|}{$\mathrm{R}$} & R Square & \multicolumn{1}{c|}{$\begin{array}{c}\text { Adjusted R } \\
\text { Square }\end{array}$} & $\begin{array}{l}\text { Std. Error of } \\
\text { the Estimate }\end{array}$ \\
\hline 1 & $.416^{\mathrm{a}}$ & .173 & .156 & 2.98077 \\
\hline
\end{tabular}

a. Predictors: (Constant), kualitas pelayanan teller 
Berdasarkan dari hasil pengujian R2 di atas menunjukkan nilai R Square atau koefisien determinasi diperoleh adalah 17,3 (17,3\%) yang dapat diartikan bahwa variabel kualitas pelayanan (X) memiliki kontribusi sebesar 17,3\% terhadap kepuasan nasabah (Y) dan $82,7 \%$ lainnya dipengaruhi oleh faktor-faktor yang tidak dijelaskan dalam penelitian ini.

\section{Pembahasan}

Penelitian ini bertujuan untuk menguji pengaruh kualitas pelayanan teller terhadap kepuasan nasabah dan seberapa besar pengaruh pelayanan teller terhadap kepuasan nasabah pada BMT UGT Capem Ketompen Pajarakan. Kualitas pelayanan adalah suatu aktifitas atau serangkaian aktifitas yang bersifat tidak kasat mata yang terjadi akibat adanya interaksi antara konsumen dengan karyawan atau hal-hal lain yang disediakan oleh perusahaan. Kepuasan nasabah adalah tingkat perasaan seseorang setelah membandingkan kinerja (atau hasil) yang dirasakan dibandingkan dengan harapannya nasabah.

Hasil penelitian ini diperoleh dengan menyebarkan kuesioner kepada responden. Berdasarkan hasil uji t pada variabel kualitas pelayanan teller terhadap kepuasan nasabah dengan hasil $\mathrm{t}$ hitung $>\mathrm{t}$ tabel atau $3.169>2.021$ maka Ho ditolak sedangkan Ha diterima. Artinya kualitas pelayanan teller $(\mathrm{X})$ berpengaruh positif dan signifikan terhadap kepuasan nasabah (Y). Apabila kualitas pelayanan teller semakin meningkat, maka kepuasan nasabah akan semakin meningkat pula. Sebaliknya, apabila kualitas pelayanan teller semakin menurun, maka kepuasan nasabah akan semakin menurun pula.

Berdasarkan dari hasil pengujian determinasi (R2) menunjukkan nilai R Square atau koefisien determinasi diperoleh adalah 17,3 (17,3\%), artinya maka variabel kualitas pelayanan $(\mathrm{X})$ memiliki pengaruh sebesar 17,3\% terhadap kepuasan nasabah (Y) sedangkan $82,7 \%$ lainnya dipengaruhi oleh faktor-faktor yang tidak dijelaskan dalam penelitian ini. Hasil penelitian ini mendukung penelitian sebelumnnya yang telah dilakukan oleh Yulianti, bahwa kualitas pelayanan teller berpengaruh besar dan signifikan terhadap kepuasan nasabah.

Jurnal al-Idārah | 72 


\section{KESIMPULAN}

Kualitas pelayanan teller $(\mathrm{X})$ berpengaruh positif dan signifikan terhadap kepuasan nasabah (Y). Artinya, apabila kualitas pelayanan teller semakin meningkat, maka kepuasan nasabah akan semakin meningkat pula. Sebaliknya, apabila kualitas pelayanan teller semakin menurun, maka kepuasan nasabah akan semakin menurun pula.

\section{DAFTAR PUSTAKA}

Agus. Pengaruh Kualitas Pelayanan terhadap Kepuasan Nasabah PT Bank Mandiri Persero Tbk Cabang Pinrang, Skripsi, 2018.

Aida W. et al . Pengaruh Kualitas Pelayanan terhadap Kepuasan dan Word Of Mouth Mahasiswa Program Studi Diploma III Administrasi Perpajakan Fisip USU. Jurnal Manajemen \& Bisnis Vol 14 No. 02, 2014.

Lie Darwin, Efendi, dan Andy Wijaya. 2017. Pengaruh Harga dan Kualitas Pelayanan terhadap Kepuasan Pelanggan Pada PT. Kereta Api Indonesia (Persero) Stasiun Pematang Siantar. Jurnal Manajemen.Vol. 3, No. 1.

Muhammad. Bank Syariah; Analisis Kekuatan, Kelemahan, Peluang dan Ancaman (Yogyakarta: Ekonisia, 2002).

Purwaningsih, Endang dan Nurul Huda, dkk. UMKM Aspek Hukum dan Manajemen Pemasaran. (Malang: Empat Dua, 2018).

Sugiyono, Metode Penelitian Kuantitatif dan Kualitatif. (Bandung: Penerbit Alfabeta, 2016). 
Volume 2, No 2, Agustus 2021

Yashinta Mayangsari. Sistem Antrian teller Bank Mandiri Sebagai Upaya Meningkatkan Efesiensi Kecepatan Transaksi. Jurnal Ekonomi dan Bisnis vol 1, nol. 